\title{
Transcriptional regulation of copper metabolism genes in the liver of fetal and neonatal control and iron-deficient rats
}

\author{
Malgorzata Lenartowicz • Christine Kennedy • \\ Helen Hayes · Harry J. McArdle
}

Received: 13 October 2014/Accepted: 16 October 2014/Published online: 28 October 2014

(C) The Author(s) 2014. This article is published with open access at Springerlink.com

\begin{abstract}
Copper and iron metabolism have been known to interact for many years. We have previously shown, during pregnancy, that copper levels in the maternal liver rise as a consequence of iron deficiency, but that levels in the fetal liver decrease. In this paper, we measure expression of genes involved in copper metabolism in fetal and postnatal liver, to test whether alterations can explain this observation. Additionally, we study the extent to which gene expression changes in the latter stages of pregnancy and in the perinatal period. Ctrl expression levels dropped to term, rising again thereafter. There was no difference in gene expression between control and iron deficient animals. Atoxl expression remained approximately stable until term, and then there was a rise to a maximum at about Day 8. Atp7a expression levels remained constant, except for a brief drop at term. Atp $7 b$ levels, in contrast, decreased from a maximum early in gestation to low levels in the term and post-natal livers. Ceruloplasmin expression appeared to be diametrically opposite to Atp $7 b$. The other two metallochaperones showed the
\end{abstract}

M. Lenartowicz

Department of Genetics and Evolution, Institute of

Zoology, Jagiellonian University, Gronostajowa 9,

30-387 Kraków, Poland

C. Kennedy $\cdot$ H. Hayes $\cdot$ H. J. McArdle $(\bowtie)$

Rowett Institute of Nutrition and Health, University of

Aberdeen, Greenburn Road, Bucksburn,

Aberdeen AB21 9SB, UK

e-mail: h.mcardle@abdn.ac.uk same pattern of expression as Atoxl, with a decrease to term, a rise at Day 1, or a rise after birth followed by a brief decrease at about Day 3. None of the genes were significantly affected by iron deficiency, suggesting that changes in expression cannot explain the altered copper levels in the fetal and neonatal liver.

Keywords Copper-iron interactions - Perinatal development - Metallochaperones · ATP7A - ATP7B · Copper metabolism $\cdot$ Hooded Lister rats

\section{Introduction}

Copper is a micronutrient, essential for normal growth and development. It is a cofactor for enzymes that catalyze reactions used in fundamental metabolic processes, including respiratory oxidation, neurotransmitter synthesis, iron uptake regulation, and connective tissue formation (Lutsenko et al. 2007). However, an excess of copper has the potential to be toxic, as the ions are potent generators of free radicals, which could lead to oxidative damage of proteins, lipids and nucleic acids (Lutsenko et al. 2007; Van den Berghe and Klomp 2010; Velthuis et al. 2009). Consequently, organisms have developed complex and genetically regulated control mechanisms for maintaining the balance between essential and toxic copper levels.

In mammals, copper is absorbed mainly in the stomach and duodenum and is transported in plasma to 
the liver (Van den Berghe and Klomp 2010), the main organ responsible for copper homeostasis. The copper is stored primarily as a copper-metallothionein complex (Bauerly et al. 2005; Czachor et al. 2002; Davis and Cousins 2000) and is excreted through bile (Huster et al. 2006; Wijmenga and Klomp 2004).

Copper uptake by hepatocytes is mediated by the high affinity copper transporter 1 (CTR1) (Kuo et al. 2001, 2006). In the cell the copper is bound to metallochaperones, and transported to the different compartments of the cell (O'Halloran and Cizewski Culotta 2000). Different chaperones deliver the copper to different enzymes. The copper chaperone of superoxide dismutase (CCS) partitions copper for SOD synthesis (Wong et al. 2000; Bertinato et al. 2003; Prohaska et al. 2003). Copper ions bound to COX 17 chaperone are transported to mitochondria where they are bound to the subunits of the cytochrome-c oxidase (Nevitt et al. 2012; Kako et al. 2004; Punter and Glerum 2003). ATOX1 transport copper to the trans-Golgi network where it is incorporated into the two Cu-transporting ATPases, ATP7A and ATP7B proteins (Barry et al. 2010; Pufahl et al. 1997; Lutsenko et al. 2007, 2008). In hepatocytes, ATP7B delivers copper to ceruloplasmin, a major form of copper in serum. It is also the pathway of excretion of copper into the bile (Huster et al. 2006; La Fontaine et al. 2001; Wijmenga and Klomp 2004). ATP7A is not expressed in the adult liver, but in other tissues is involved in copper excretion and absorption. These data are summarized in Fig. 1.

Metabolic interactions between the two essential elements, copper and iron, have been known for many years (McArdle 1992; McArdle et al. 2008; Gambling et al. 2011). In the early part of the last century it was shown that copper could facilitate hemoglobin formation in anemic rats (Hart et al. 1928). More recently, it has been demonstrated that iron metabolism is critically dependent on ferroxidases, most of which are copper enzymes. How iron alters copper metabolism is not so well understood. We have previously shown that iron deficiency results in accumulation of copper in the maternal, but not fetal liver. How this occurs is not clear but is presumably related to alterations in gene expression in one of the major organs involved in iron and copper transfer from mother to fetus. In this paper, therefore, we examine the effect of iron deficiency on expression of the genes of copper metabolism, with a view to identifying the changes

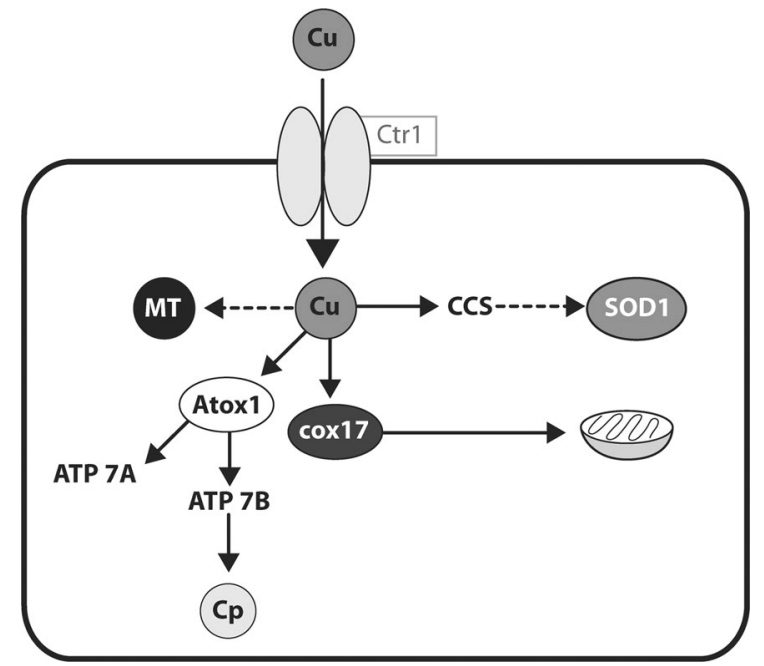

Fig. 1 The model used to study gene expression in this paper. Copper is taken up across the cell membrane, binds to the relevant chaperone and is incorporated into the target protein. More information is given in the text in the relevant section

that could explain alterations in copper levels in the maternal and fetal livers.

\section{Materials and methods}

Animals and diets

\section{Ethical approval}

All animal experiments were performed in the Bioresources Unit of the Rowett Institute of Nutrition and Health, under licence from the United Kingdom Home Office in accordance with the UK Animals (Scientific Procedures) Act, 1986. The study was approved by the UK Home Office (Project Licence PPL 60/3606) and the Rowett Institute of Nutrition and Health Ethics Review Committee (approval ID SA09/03E).

\section{Experimental diets}

The experimental diets were based on a dried egg albumin diet and conformed to American Institute of Nutrition guidelines for laboratory animals (Williams and Mills 1970). $\mathrm{FeSO}_{4}$ was added to achieve levels of added iron of 50 (control diet) and 7.5 (iron deficient diet) $\mathrm{mg} \mathrm{kg}^{-1}$. Dietary ingredients were purchased 
from Mayjex Ltd (Chalfont-St Peter, UK), BDH Chemicals (Poole, UK) or Sigma (Poole, UK). Diet formulations have all previously been used (Gambling et al. 2003a).

\section{Experimental animals and tissue collection}

Experiments were performed using weanling female rats of the Rowett Hooded Lister strain. Animals were housed in cages under constant conditions (temperature, humidity, 12L:12D illumination photoperiod). Female weanling rats were fed control diet for 2 weeks, before being randomised into two groups. The first group remained on the control diet throughout the experiment, including pregnancy, whilst the scond were given the iron deficient diet for 4 weeks prior to mating. The rats were mated with males of the same strain. Mating was confirmed by detection of a vaginal plug, and this day was denoted as Day 0.5. The female rats were maintained on the same diet throughout pregnancy.

At times stated in the results, 8 rats from each group were killed as described below. At parturition, blood and tissue samples were taken from 8 dams and their litters, from birth the control and iron deficient groups. Following parturition all remaining dams fed on control diet during pregnancy continued on this diet. At the same time dams fed on the iron deficient diet during pregnancy were split into two groups, half remained on the iron deficient diet, whilst the diet for the remaining dams was changed to the control diet. Within $24 \mathrm{~h}$ of birth all litters were culled to 8 pups, with male pups being kept preferentially. Over the next 10 days, there were 4 time points at which 8 dams and their litters from each of the now 3 groups, were killed and blood and tissue samples taken. These time points were 1, 3, 7 and 10 days after birth.

Dams were anesthetized with isoflurane, and maternal blood samples collected from the heart. The dams were then killed by cervical dislocation. Tissue samples were also taken from the dam. The fetuses or neonates were weighed, and then killed by decapitation. Blood samples were collected from each of the neonates, and pooled to provide a representative litter sample. Organs were weighed and snap frozen in liquid nitrogen before being stored at $-80{ }^{\circ} \mathrm{C}$. In order to obtain representative samples, tissues from the 3
Table 1 Primer list used for real-time quantitative RT-PCR analysis

\begin{tabular}{ll}
\hline Gene & Sequence/cat. no \\
\hline $\begin{array}{l}\text { MWG Eurofins } \\
\text { primers made to order }\end{array}$ & Sequence \\
Atp7a forward & $5^{\prime}$-aggcaaattccagtggatg-3' \\
Atp7a reverse & $5^{\prime}$-atgaggagcgatccattctg-3' \\
Atp7b forward & $5^{\prime}$-acatgctaatcccagcagt-3' \\
Atp7b reverse & $5^{\prime}$-gatgagcacatccatgttgg-3' \\
Quantitect primer assays & Cat. no \\
Atox1 & QT01081696 \\
Ctr1 (Slc31a1) & QT00175161 \\
Cox17 & QT00183827 \\
CCS & QT00181286 \\
Cp1 & QT00495075 \\
UBQc & QT00372596 \\
\hline
\end{tabular}

pups closest to the litter median, determined by body weight, were pooled and ground. These pooled samples were used for all future analysis.

\section{RNA isolation}

Total RNA was prepared from $50 \mathrm{mg}$ of frozen liver tissue by homogenizing in cold TRI reagent (Helena Biosciences, Sunderland, UK) according to the manufacturer's instructions. RNA were precipitated in isopropanol and dissolved in DNAse, RNASe free water. Concentration of RNA in samples was measured in a NanoDrop ${ }^{\mathrm{TM}}$ 2000c spectrophotometer (Thermo Scientific) OD 260/280 and purify of RNA was estimated using OD 260/230. RNA integrity was determined using Agilent 2100 Bioanalyzer ${ }^{\circledR}$ (Agilent Technologies) according to the manufacturer's instructions. To avoid contamination of obtained RNA with genomic DNA, 1 ug of total RNA samples were treated with ribonuclease (RNase)-free Dnase 1 Amplification Grade (Invitrogen Ltd, Paisley, UK), before the reaction of reverse transcription. Reverse transcription was performed according to the manual instruction using the Taqman RT Reagent Kit (Applied Biosystem) from $200 \mathrm{ng}$ of DNAse-treated RNA.

Real time PCR reaction

Real-time quantitative PCR was performed using the 7700 Real Time PCR system (Applied Biosystem) and 


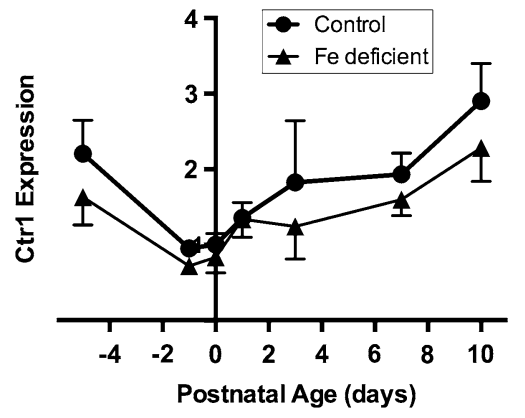

Fig. 2 Developmental changes in the expression level of the Ctrl gene in the liver of the control and Fe deficient fetus and neonates. The mRNA level are shown relative to ubiquitin. Values with different letters differ significantly $(p<0.05)$. Data are expressed as mean \pm SEM

the primers specific for analysed gene (Table 1). Primers for Atp7a and Atp7b genes were designed, using Primer Express software and were ordered in MWG Eurofins Company, sequence of primers is showed in Table 1. Primers for metallochaperones, Ctrl, ceruloplasmin (Cp) and ubiquitin genes (Table 1) obtained from Qiagen. Quantification was performed relative ubiquitin control reaction. To confirm amplification specificity, the PCR products from each primer pair were subjected to melting curve analysis and subsequent agarose gel electrophoresis. The relative expression of each gene was calculated as $2^{-\Delta \Delta \mathrm{CT}}$.

\section{Statistical analysis}

All data are expressed as mean \pm SEM. Comparison of the relative expression level were made by one-way ANOVA followed by the NIR Fisher post hoc test. Student $t$ test was used when comparing data between control and Fe-deficient rats. Values of $p<0.05$ were considered statistically significant.

\section{Results}

In the liver of both normal and iron deficient rats expression of the Ctrl gene decreased from 17.5 to the 21.5 days gestation, then increased postnatally. There was no significant difference in expression between control and Fe deficient livers, though there was an apparent trend ( $p=0.07$ ) (Fig. 2). After entry to the hepatocytes, copper is bound to chaperone proteins. We measured mRNA levels of Atoxl in control and

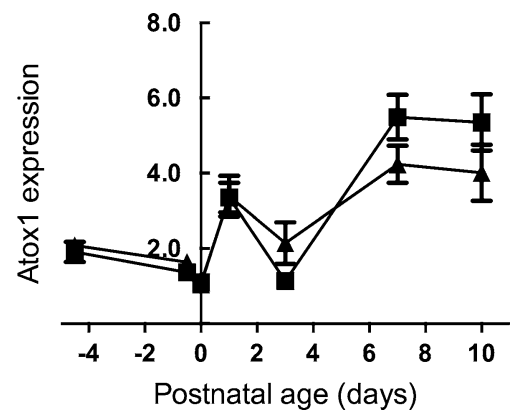

Fig. 3 Expression pattern of the ATOX1 gene in the liver of the control and $\mathrm{Fe}$ deficient rats between 17.5 and 21.5 of gestation and Day 0 to Day 10 of the postnatal life. The mRNA level is shown relative to ubiquitin. Values with different letters differ significantly. Data are expressed as mean \pm SEM

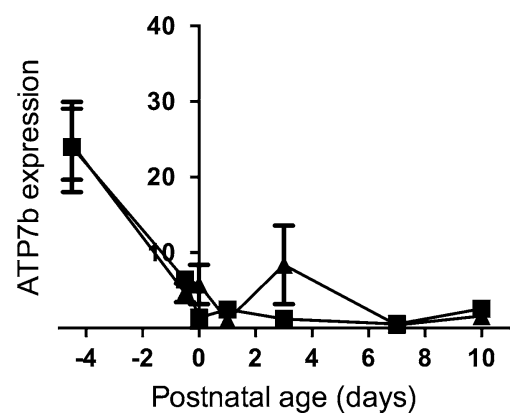

Fig. 4 Developmental changes in the expression level of the $A t p 7 b$ gene in the liver of the control and Fe deficient fetus and neonates. The mRNA level is shown relative to ubiquitin. Values with different letters differ significantly $(p<0.05)$

iron deficient fetal livers. There were no significant differences between the two groups at any stage of gestation or postnatal life (Fig. 3). As with Ctrl, levels decreased to term. After birth, levels rose in both control and Fe deficient pups. However, there was a decrease at Day 3. Currently, we do not have an explanation for this observation.

ATOX1 protein delivers the copper ions to the Golgi apparatus, where they bind to the $\mathrm{Cu}$-transporting ATPases, ATP7A and ATP7B. Both Atp7 $a$ and $7 b$ genes were expressed in the fetal liver. Levels dropped to term, and did not change subsequently for Atp $7 b$ (Fig. 4). In contrast, Atp7a expression rose briefly at Day 3 (see above for Atoxl) thereafter returning to levels seen at Day 0 (Fig. 5). In adult liver, ATP7A expression is negligible. However, in the neonates, expression levels were significantly higher than Atp $7 b$, 


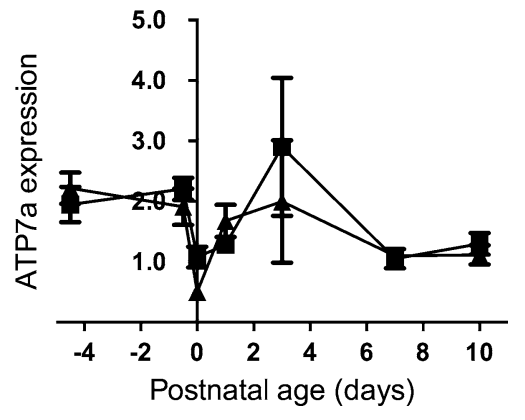

Fig. 5 The Atp7a mRNA profile of the liver of the control and Fe deficient fetus and neonates. The mRNA level is corrected relative to ubiquitin. Values with different letters differ significantly $(p<0.05)$

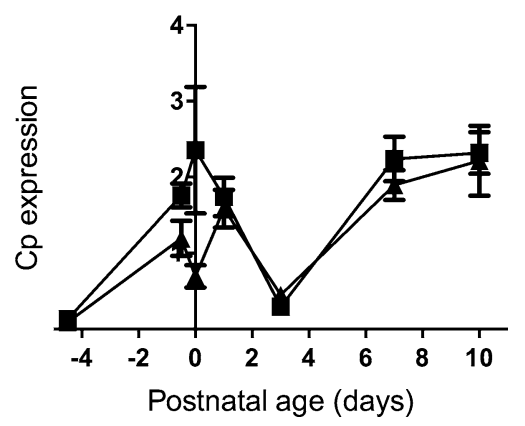

Fig. 6 Ceruloplasmin mRNA level in the liver through developmental stages of the control and Fe deficient fetus and neonates. The mRNA level is shown relative to ubiquitin. Values with different letters differ significantly $(p<0.05)$. Data are expressed as mean $\pm \mathrm{SEM}$

implying that the former may play a significant role in hepatic copper metabolism in the neonate.

The ATP7B Cu-ATPase delivers copper to ceruloplasmin, so we determined expression levels of $C p$ in the fetal and neonatal liver. Before birth, expression increased in the fetal liver, dropped to their lowest levels at Day 3 and thereafter increased (Fig. 6). There was no difference in mRNA levels between control and Fe-deficient animals. Further, expression levels of $C p$ were not correlated with expression of Atp $7 b$ (data not shown).

Copper bound to CCS is used for SOD1 synthesis. In both control and iron deficient animals, $C C S$ levels dropped during pregnancy, rose in the immediate postnatal period, then fell again at Day 3 (Fig. 7). The increase in expression after Day 3 was significantly greater in controls than in animals from iron deficient dams.

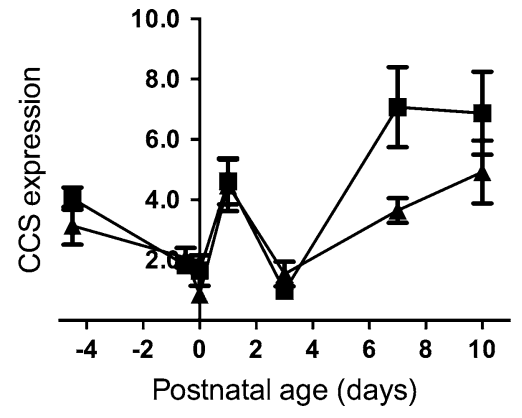

Fig. 7 Relative expression of the $C C S$ gene using ubiquitin as the endogenous normalization control in the liver of the control and $\mathrm{Fe}$ deficient fetus and neonates. Values with different letters differ significantly $(p<0.05)$. Data are expressed as mean \pm SEM

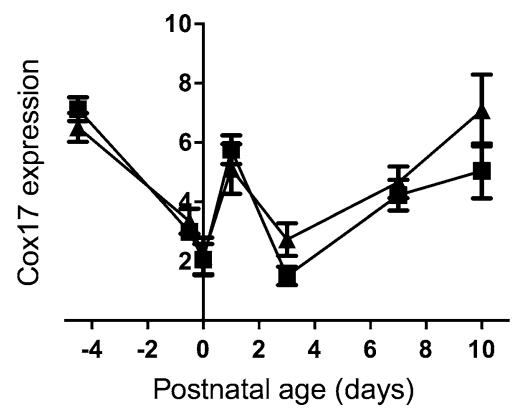

Fig. 8 Developmental changes in the expression level of the Cox17 gene in the liver of the control and $\mathrm{Fe}$ deficient fetus and neonates. The mRNA level is shown relative to ubiquitin. Values with different letters differ significantly $(p<0.05)$. Data are expressed as mean \pm SEM

Finally, Cox 17 expression was measured. As with the other chaperones, there was a drop followed by a rise at birth, thereafter falling back at Day 3 (Fig. 8). From then, there was a rise until the end of the experiment at Day 10 post-natal. The difference between control and Fe-deficient animals was not significant.

\section{Discussion}

Copper and iron are micronutrients essential for normal fetal development. Both are transferred from mother to fetus across the placenta (Gambling et al. 2003b; Hardman et al. 2007; McArdle et al. 2003). The metabolisms of the two elements have been known to interact for many years (reviewed in Collins et al. 2010; McArdle 1992; Gambling et al. 2011). Iron 
release from cells is dependent on copper oxidases; hephaestin in the gut, ceruloplasmin in the liver and zyklopen in the placenta. Copper deficiency, therefore, results in accumulation of iron in the liver, and in the kidney and brain. The effect of iron deficiency on copper metabolism is not so well studied. We have shown, as have others (Sherman and Moran 1984; Sherman and Tissue 1981) that, during pregnancy, copper levels in the fetal liver decrease in response to maternal iron deficiency, in contrast to the maternal liver, where iron deficiency results in an increase in copper levels (Gambling et al. 2004). How this occurs is not known. In this paper, we test the hypothesis that alterations in expression levels of the genes involved in copper metabolism are involved in the mechanism. Further, we also examine how gene expression changes as development proceeds through late gestation and the early neonatal period.

Terao and Owen (1977) reported that in rats, the copper concentration in the fetal liver was highest at day 18 of pregnancy and decreased to day 21. After birth, copper levels significantly increased up to postnatal day 7. From then, levels remained high until about the second week of life, thereafter decreasing to adult levels by six weeks of age (Terao and Owen 1977). In mammalian cells, copper import is primarily mediated by CTR1 protein (Ansede et al. 2009; Kim et al. 2009; Lee et al. 2002; Nose et al. 2006; Van den Berghe and Klomp 2010). Kuo et al. (2006) showed that in mice and rats CTR1 expression is regulated by copper status (Bauerly et al. 2005; Kuo et al. 2006). In the present study we found that $\mathrm{Ctrl}$ gene expression matched these patterns. We also found that in neonatal rats after birth $C t r 1$ expression in the liver is rather low and gradually increased. There was no apparent effect of iron deficiency on expression of the Ctrl gene at any stage in gestation.

Following uptake across the cell membrane, copper is bound to one of a class of proteins called metallochaperones. Several have been identified, each of which will deliver copper from the membrane to a particular target protein. These targets are shown in Fig. 1.

Anti-oxidant 1 protein (ATOX1) (Klomp et al. 1997), transports $\mathrm{Cu}$ to ATP7A and ATP7B, the $\mathrm{Cu}-$ transport ATPases (Lutsenko et al. 2007, 2008; Van den Berghe and Klomp 2010). In adult liver, ATP7A expression is extremely low (Lenartowicz et al. 2010). However, in the fetus and neonate, both ATPases are expressed. Interestingly, expression levels of Atp $7 a$, but not Atp7b, and Atoxl are inversely proportional. Why this should be is not clear, but it could be related to either regulation of Atp7a by ATOX1, or possibly to the transcription factor function of ATOX1. Itoh and co-workers showed that copper promotes transport of ATOX1 protein to the nucleus where it is bound to the promoter of regulated genes resulting in up-regulation of Cycline D1, (Ccnd 1), and extracellular SOD (SOD3) genes (Itoh et al. 2008, 2009).

In hepatocytes, ATP7B protein is localized in the trans-Golgi network (Schaefer et al. 1999; Bingham et al. 1996) where it is involved in the process of $\mathrm{Cu}$ binding to apo-ceruloplasmin (Lutsenko et al. 2007; Terada et al. 1998). It also transfers copper from the hepatocyte to the bile in the case of copper excess (Bauerly et al. 2005; Roelofsen et al. 2000; Huster et al. 2006; Wijmenga and Klomp 2004). In the fetus, the bile duct is not patent, and copper accumulates in the liver (Guo et al. 2005; Lutsenko et al. 2003; La Fontaine and Mercer 2007; Mercer et al. 2003; Schaefer et al. 1999), although it may also be that the copper is accumulated in order to provide a store for the perinatal period.

This is the first study to compare Atp $7 b$ and Atp7a expression levels in the liver of fetal and neonatal animals. Previous work from our laboratories showed developmental regulation of Atp7a expression in the liver of neonatal mice (Lenartowicz et al. 2010, 2011) but little is known about expression pattern of Atp $7 b$ in the liver. Here, we show that in the liver of the neonatal rats Atp $7 a$ expression dropped in the perinatal period, but then stabilised, while Atp $7 b$ expression remained low. The data suggest that, in the liver of very young animals, Atp7a/ATP7A plays the dominant role in regulation of copper metabolism. By adulthood, this is reversed, and Atp7b/ATP7B is the only transporter. Alternatively, the data could reflect the relatively important role the fetal and neonatal liver plays in haematopoiesis, and the high concentration of haematopoietic cells in the liver.

Ceruloplasmin is a ferroxidase, containing $6 \mathrm{Cu}$ atoms per molecule protein, and is required for oxidation of $\mathrm{Fe} 2+$ to $\mathrm{Fe} 3+$ and thus for iron efflux from the cells via ferroportin. Ceruloplasmin is also the major plasma copper binding protein (Tran et al. 2002; Hellman and Gitlin 2002; Broderius et al. 2010; Prohaska 2011). Incorporation of copper to the ceruloplasmin is mediated by ATP7B protein 
(Terada et al. 1998). During development, ceruloplasmin expression starts very early (Fleming and Gitlin 1990; Lee et al. 1993) and mRNA in the liver was detected at E15. Expression increases between 17th and 20th day of gestation and drops just before delivery (Fleming and Gitlin 1990). Such findings closely overlap with our own results. Terao and Owen (1977) reported that ceruloplasmin protein levels in the liver of rat pups increase sharply in the first $24 \mathrm{~h}$ after birth, which also fits with our data. Ceruloplasmin gene expression unexpectedly significantly decreased at Day 3. In rats in the 3th day postpartum copper levels in the mother's milk are highest and drop thereafter (Terao and Owen 1977). We speculate that decreasing ceruloplasmin synthesis at this stage may protect the neonates against excess copper. As copper in the milk decreases thereafter, $C p$ levels rise again. Both in vitro experiments on isolated hepatocytes (McArdle et al. 1990) and in vivo studies on mice and rats indicated that copper deficiency have no impact on ceruloplasmin mRNA in the liver (Prohaska 2011; Mercer et al. 1991; Mostad and Prohaska 2011) and our current data also show no difference between control and $\mathrm{Fe}$ deficient livers.

Copper, zinc superoxide dismutase (SOD1) protects cells against reactive oxygen species that are generated during the processes of oxidative metabolism. Activity of SOD1 is closely dependent on its copper chaperone, CCS, which is necessary for insertion of $\mathrm{Cu}$ ions to apo-SOD1 (Wong et al. 2000). Copper supplementation results in decreasing of CCS and SOD1 mRNA level both in the liver and peripheral mononuclear blood cells (Suazo et al. 2008; Han et al. 2009). Here, we found a significant decrease in CCS expression, which may also be caused by the increase in $\mathrm{Cu}$ levels. It is known that in pups born from Fe deficient mothers copper concentration in the liver is significantly increased (Sherman and Moran 1984; Sherman and Tissue 1981). In both investigated group of rats CCS mRNA level rapidly and significantly increased during first $24 \mathrm{~h}$ of postnatal life.

Cytochrome c oxidase is a terminal complex in the respiratory chain (Oswald et al. 2009; Voronova et al. 2007). Uptake, transport and delivery of the copper ions to the enzyme are complicated processes; requiring activity at least six copper chaperones (Voronova et al. 2007). One of these is COX 17, a small hydrophobic protein which contains copper binding domains, binds and transports copper ions in the cytoplasm and also participates in shuttling $\mathrm{Cu}$ ions through the mitochondrial membrane to the intermembrane mitochondrial space (Oswald et al. 2009; Voronova et al. 2007; Kako et al. 2004; Punter and Glerum 2003). In rats Cox 17 expression in the brain and heart was detected in prenatal life and it was shown that the expression profile was age- and tissuedependent and changes during development (Kako et al. 2000). In the present study we analysed expression of the Cox 17 in the liver of the fetus and neonatal rats and found similar results. In the iron deficient animals after birth, Cox17 expression was higher than control. This may be related to different nutritional profiles in the iron-deficinet dams, but may also be a consequence of reduced mitochondrial function in the iron deficient animals.

In summary, the data presented show that, while there are marked changes in the expression of the genes of copper metabolism while development proceeds, the consequences of iron deficiency are limited and cannot explain the increasing copper levels in the iron deficient liver.

Acknowledgments The authors' work is supported by Scottish Government (Rural and Environmental Scientific and Analytical Services). We are grateful to Ms Val Stevens for analytical and technical assistance and to the Biological Resource Facility staff for husbandry and maintenance of the experimental animals. The authors declare no conflicts of interest.

Open Access This article is distributed under the terms of the Creative Commons Attribution License which permits any use, distribution, and reproduction in any medium, provided the original author(s) and the source are credited.

\section{References}

Ansede JH, Wright MR, Claire RLS 3rd, Hart RW, Gefroh HA, Brouwer KR (2009) Characterization of sandwich-cultured hepatocytes as an in vitro model to assess the hepatobiliary disposition of copper. Drug Metab Dispos 37:969-976

Barry AN, Shinde U, Lutsenko S (2010) Structural organization of human $\mathrm{Cu}$ - transporting ATPases: learning from building blocks. J Biol Inorg Chem 15:47-59

Bauerly KA, Kelleher SL, Lönnerdal B (2005) Effects of copper supplementation on copper absorption, tissue distribution, and copper transporter expression in an infant rat model. Am J Physiol Gastrointest Liver Physiol 288:G1007G1014

Bertinato J, Iskandar M, L'Abbé MR (2003) Copper deficiency induces the upregulation of the copper chaperone for $\mathrm{Cu}$ / $\mathrm{Zn}$ superoxide dismutase in weanling male rats. J Nutr 133:28-31 
Bingham MJ, Ong TJ, Ingledew WJ, McArdle HJ (1996) ATPdependent copper transporter, in the Golgi apparatus of rat hepatocytes, transports $\mathrm{Cu}(\mathrm{II})$ not $\mathrm{Cu}(\mathrm{I})$. Am J Physiol 271:G741-G746

Broderius M, Mostad E, Wendroth K, Prohaska JR (2010) Levels of plasma ceruloplasmin protein are markedly lower following dietary copper deficiency in rodents. Comp Biochem Physiol C: Toxicol Pharmacol 151:473-479

Collins JF, Prohaska JR, Knutson MD (2010) Metabolic crossroads of iron and copper. Nutr Rev 68:133-147

Czachor DJ, Cherian MG, Koropatnick J (2002) Reduction of copper and metallotionein in toxic milk mice by tetrathiomolybdate, but not deferiprone. $\mathrm{J}$ Inorg Biochem 88:213-222

Davis SR, Cousins RJ (2000) Metallotionein expression in animals: a physiological perspective and functions. J Nutr 130:1085-1088

Fleming RE, Gitlin JD (1990) Primary structure of rat ceruloplasmin and analysis of tissue-specific gene expression during development. J Biol Chem 265:7701-7707

Gambling L, Danzeisen R, Fosset C, Andersen HS, Dunford S, Srai SK, MCArdle HJ (2003a) Iron and copper interactions in development and the effect on pregnancy outcome. J Nutr 133:1554S-1556S

Gambling L, Dunford S, Wallace DI, Zuur G, Solanky N, Srai SKS, McArdle HJ (2003b) Iron deficiency during pregnancy affects post-natal blood pressure in the rat. J Physiol 552:603-610

Gambling L, Dunford S, McArdle HJ (2004) Iron deficiency in the pregnant rat has differential effects on maternal and fetal copper levels. J Nutr Biochem 15:366-372

Gambling L, Kennedy C, McArdle HJ (2011) Iron and copper in fetal development. Semin Cell Dev Biol 22:637-644

Guo Y, Nyasae L, Braiterman LT, Hubbard AL (2005) NH2terminal signals in ATP7B Cu-ATPase mediated its $\mathrm{Cu}$ dependent anterograde traffic in polarized hepatic cells. Am J Physiol 289:G904-G916

Han H, Archibeque SL, Engle TE (2009) Characterization and identification of hepatic mRNA related to copper metabolism and homeostasis in cattle. Trace Elem Res 129:130-136

Hardman B, Michalczyk A, Greenough M, Camakaris J, Mercer J, Ackland L (2007) Distinct functional roles for the Menkes and Wilson copper translocating P-type ATPases in human placental cells. Cell Physiol Biochem 20: 1073-1084

Hart E, Steenbock H, Waddell J, Elvehjem C (1928) Iron in nutrition. VII. Copper as a supplement to iron for hemoglobin building in the rat. J Biol Chem 77:797-812

Hellman NE, Gitlin JD (2002) Ceruloplasmin metabolism and function. Annu Rev Nutr 22:439-458

Huster D, Finegold MJ, Morgan CT, Burkhead JL, Nixon R, Vanderwerf SM, Gilliam CT, Lutsenko S (2006) Consequences of copper accumulation in the livers of the Atp $7 b$ -/- (Wilson disease gene) knockout mice. Am J Pathol 168:423-434

Itoh S, Kim HW, Nakagawa O, Ozumi K, Lessner SM, Aoki H, Akram K, McKinney RD, Ushio-Fukai M, Fukai T (2008) Novel role of antioxidant-1 (Atox 1) as a copper-dependent transcription factor involved in cell proliferation. J Biol Chem 283:9157-9167
Itoh S, Ozumi K, Kim HW, Nakagawa O, McKinney RD, Folz RJ, Zelko IN, Ushio-Fukai M, Fukai T (2009) Novel mechanism for regulation of extracellular SOD transcription and activity by copper: role of antioxidant- 1 . Free Radic Biol Med 46:95-104

Kako K, Tsumori K, Ohmasa Y, Takahashi Y, Munekata E (2000) The expression of Cox 17p in rodent tissues and cells. Eur J Biochem 267:6699-6707

Kako K, Takehara A, Arai H, Onodera T, Takahashi Y, Hanagata H, Ogra Y, Takagi H, Kodama H, Suzuki KT, Munekata E, Fukamizu A (2004) A selective requirement for copper-dependent activation of cytochrome c oxidase by Cox 17p. Biochem Biophys Res Commun 324: 1379-1385

Kim H, Son HY, Bailey SM, Lee J (2009) Deletion of hepatic $\mathrm{Ctr} 1$ reveals its function in copper acquisition and compensatory mechanisms for copper homeostasis. Am J Physiol Gastrointest Liver Physiol 296:G356-G364

Klomp WL, Lin SJ, Yuan SD, Klausner RD, Culotta VC, Gitlin JD (1997) Identification and functional expression of HAH1: a novel human gene involved in copper homeostasis. J Biol Chem 272:9221-9226

Kuo YM, Zhou B, Cosco D, Gitschier J (2001) The copper transporter CTR1 provides an essential function in mammalian embryonic development. Proc Natl Acad Sci USA 98:6836-6841

Kuo YM, Gybina AA, Pyatskowit JW, Gitschier J, Prohaska JR (2006) Copper transport protein (Ctr1) levels in mice are tissue specific and dependent on copper status. J Nutr 136:21-26

La Fontaine S, Mercer JFB (2007) Trafficking of the copperATPases, ATP7A and ATP7B: role in copper homeostasis. Arch Biochem Biophys 463:149-167

La Fontaine S, Theophilios MB, Firth SD, Gould R, Porton RG, Mercer JFB (2001) Effect of the toxic milk mutation (tx) on the function and intracellular localization of the Wnd, the murine homologue of the Wilson copper ATPase. Hum Mol Genet 10:361-370

Lee SH, Lancey R, Montaser A, Madani N, Linder MC (1993) Ceruloplasmin and copper transport during the latter part of gestation in the rat. Proc Soc Exp Biol Med 203:428-439

Lee J, Pena MM, Nose Y, Thiele DJ (2002) Biochemical characterization of the human copper transporter Ctr1. J Biol Chem 277:4380-4387

Lenartowicz M, Wieczerzak K, Krzeptowski W, Dobosz P, Grzmil P, Starzyński R, Lipiński P (2010) Developmental changes in the expression of the Atp7a gene in the liver of mice during the postnatal period. J Exp Zool A Ecol Genet Physiol 313:209-217

Lenartowicz M, Starzyński R, Wieczerzak K, Krzeptowski W, Lipiński P, Styrna J (2011) Alterations in the expression of the Atp $7 a$ gene in the early postnatal development in the mosaic mutant mice $\left(A t p 7 a^{m o-m s}\right)$ - an animal model of Menkes disease. Gene Expr Patterns 11:41-47

Lutsenko S, Tsivkovskii R, Walker JM (2003) Functional properties of the human copper-transporting ATPase ATP7B (the Wilson's disease protein) and regulation by metallochaperone Atox1. Ann N Y Acad Sci 986:204-211

Lutsenko S, Barnes NL, Bartee MY, Dymitriev OY (2007) Function and regulation of human copper-transporting ATPases. Physiol Rev 87:1011-1046 
Lutsenko S, Gupta A, Burkhead JL, Zuzel V (2008) Cellular multitasking: the dual role of human $\mathrm{Cu}$-ATPases in cofactor delivery and intracellular copper balance. Arch Biochem Biophys 476:22-32

McArdle HJ (1992) The transport of iron and copper across the cell membrane: different mechanisms for different metals? Proc Nutr Soc 51:199-209

McArdle HJ, Mercer JF, Sargeson AM, Danks DM (1990) Effects of cellular copper content on copper uptake and metallothionein and ceruloplasmin mRNA levels in mouse hepatocytes. J Nutr 120:1370-1375

McArdle HJ, Danzeisen R, Fosset C, Gambling L (2003) The role of the placenta in iron transfer from mother to fetus and the relationship between iron status and fetal outcome. Biometals 16:161-167

McArdle HJ, Andersen HS, Jones H, Gambling L (2008) Copper and iron transport across the placenta: regulation and interactions. J Neuroendocrinol 20:427-431

Mercer JF, Grimes A, Danks DM, Rauch H (1991) Hepatic ceruloplasmin gene expression is unaltered in the toxic milk mouse. J Nutr 121:894-899

Mercer JF, Barnes N, Stevenson J, Strausak D, Llanos RM (2003) Copper-induced trafficking of the Cu-ATPases: a key mechanism for copper homeostasis. Biometals 16:175-184

Mostad EJ, Prohaska JR (2011) Glycosylphosphatidylinositollinked ceruloplasmin is expressed in multiple rodent organs and is lower following dietary copper deficiency. Exp Biol Med (Maywood) 236:298-308

Nevitt T, Ohrvik H, Thiele DJ (2012) Charting the travels of copper in eukaryotes from yeast to mammals. Biochim Biophys Acta 1823:1580-1593

Nose Y, Rees EM, Thiele DJ (2006) Structure of the Ctr1 copper trans'PORE'ter reveals novel architecture. Trends Biochem Sci 31:604-607

O’Halloran TV, Cizewski Culotta V (2000) Metallochaperones, an intracellular shuttle service for metal ions. J Biol Chem 275:25057-25060

Oswald C, Krause-Buchholz U, Rödel G (2009) Knockdown of human COX17 affects assembly and supramolecular organization of cytochrome c oxidase. J Mol Biol 389: 470-479

Prohaska JR (2011) Impact of copper limitation on expression and function of multicopper oxidases (ferroxidases). Adv Nutr 2:89-95

Prohaska JR, Broderius M, Brokate B (2003) Metallochaperone for $\mathrm{Cu}, \mathrm{Zn}$-superoxide dismutase (CCS) protein but not mRNA is higher in organs from copper-deficient mice and rats. Arch Biochem Biophys 417:227-234

Pufahl RA, Singer CP, Peariso KL, Lin SJ, Schmidt PJ, Fahrni CJ, Culotta VC, Penner-Hahn JE, O’Halloran TV (1997) Metal ion chaperone function of the soluble $\mathrm{Cu}(\mathrm{I})$ receptor Atx1. Science 278:853-856

Punter FA, Glerum DM (2003) Mutagenesis reveals a specific role for Cox 17p in copper transport to cytochrome oxidase. J Biol Chem 278:30875-30880
Roelofsen H, Wolters H, Van Luyn MJ, Miura N, Kuipers F, Vonk RJ (2000) Copper-induced apical trafficking of ATP7B in polarizedhepatoma cells provides a mechanism for biliary copper excretion. Gastroenterology 119: 782-793

Schaefer M, Hopkins RG, Failla ML, Gitlin JD (1999) Hepatocyte specific localization and copper-dependent trafficking of the Wilson's disease protein in the liver. Am J Physiol Gastrointest Liver Physiol 276:G639-G646

Sherman AR, Moran PE (1984) Copper metabolism in irondeficient maternal and neonatal rats. J Nutr 114:298-306

Sherman AR, Tissue NT (1981) Tissue iron, copper and zinc levels in offspring of iron-sufficient and iron-deficient rats. J Nutr 111:266-275

Suazo M, Olivares F, Mendez MA, Pulgar R, Prohaska JR, Arredondo M, Pizarro F, Olivares M, Araya M, González M (2008) CCS and SOD1 mRNA are reduced after copper supplementation in peripheral mononuclear cells of individuals with high serum ceruloplasmin concentration. J Nutr Biochem 19:269-274

Terada K, Nakako T, Yang XL, Iida M, Aiba N, Minamiya Y, Nakai M, Sakaki T, Miura N, Sugiyama T (1998) Restoration of holo ceruloplasmin synthesis in LEC rat after infusion of recombinant adenovirus bearing WND cDNA. J Biol Chem 273:1815-1820

Terao T, Owen CA Jr (1977) Copper metabolism in pregnant and postpartum rat and pups. Am J Physiol 232:E172E179

Tran T, Ashraf M, Jones L, Westbrook T, Hazegh-Azam M, Linder MC (2002) Dietary iron status has little effect on expression of ceruloplasmin but alters that of ferritin in rats. J Nutr 132:351-356

Van den Berghe PVE, Klomp LWJ (2010) Posttranslational regulation of copper transportes. J Biol Inorg Chem 15:37-46

Velthuis NA, Gaeth AP, Pearson RB, Gabriel K, Camakaris J (2009) The multi layered regulation of copper translocating P-type ATPases. Biometals 22:177-190

Voronova A, Meyer-Klaucke W, Meyer T, Rompel A, Krebs B, Kazantseva J, Sillard R, Palumaa P (2007) Oxidative switches in functioning of mammalian copper chaperone Cox17. Biochem J 408:139-148

Wijmenga C, Klomp LW (2004) Molecular regulation of copper excretion in the liver. Proc Nutr Soc 63:31-39

Williams RB, Mills CF (1970) The experimental production of zinc deficiency in the rat. Br J Nutr 24:989-1003

Wong PC, Waggoner D, Subramaniam JR, Tessarollo L, Bartnikas TB, Culotta VC, Price DL, Rothstein J, Gitlin JD (2000) Copper chaperone for superoxide dismutase is essential to activate mammalian $\mathrm{Cu} / \mathrm{Znsuperoxide} \mathrm{dismu-}$ tase. Proc Natl Acad Sci USA 97:2886-2891 